\title{
Modern Trends of Additional Professional Education Development for Mineral Resource Extracting
}

\author{
Olga Borisova $^{1}$, Victoria Frolova ${ }^{1}$, and Elena Merzlikina $^{2}$ \\ ${ }^{1}$ Financial University under the Government of the Russian Federation, 12599349 Leningradsky \\ Prospekt, Moscow, Russia \\ ${ }^{2}$ Moscow Polytechnic University, 10702338 Bolshaya Semenovskaya str., Moscow, Russia
}

\begin{abstract}
The article contains the results of development of additional professional education research, including the field of mineral resource extracting in Russia. The paper describes the levels of education received in Russian Federation and determines the place and role of additional professional education among them. Key factors influencing the development of additional professional education are identified. As a result of the research, the authors proved the necessity of introducing additional professional education programs on educational Internet platforms for mineral resource extracting.
\end{abstract}

\section{Introduction}

In Russia, the market of educational services in the sphere of additional education is being transformed. Until recently consumers of educational services market came to universities for a higher national diploma. Since September 1, 2013, the Ministry of Education of the Russian Federation has abolished these diplomas for programs related to additional education. In addition, in recent years, the system of professional standards of Russia, included in the register of the Ministry of Labor of the Russian Federation, has been created, which contributes to the definition of skill levels, training and practical implementation, for example, Standard of Mining Engineer. In international practice, international of professional standards are widely applied, for example, international management accounting certification (CIMA), international certification of financial management (IFA). Since 2011, Russian market for educational services has been significantly influenced by the merger of a number of large universities, which provide educated stuff for many sectors of the Russian economy. Today about 50 universities in Russia are training specialists in the field of mineral resource extracting. It is being conducted according to the bachelor's, master's, postgraduate programs, as well as a number of retraining and advanced training programs.

Currently, additional education programs in many universities, including national mineral resource institutions, need to be modernized and attractive for potential clients. The purpose of the study was to identify effective areas for additional professional education development. Object - additional professional education. Subject - problems arising in implementation of programs for additional mineral resource extracting education. The practical significance of research is proved by applying its results in the process of additional 
professional mineral resource extracting education, in accordance with current trends.

\section{Materials and Methods}

The ground of the research is based upon the papers of the scholars which observe the issues of additional professional education. Basic moments of mineral resource extracting higher school development in Russia are shown in the works of some domestic scholars [12]. The issues of modern knowledge estimation system formation researched by V. Frolova, O. Borisova [3-5]. The matters of pedagogical personnel training described by many Russian and foreign scientists [6-8]. Regional and sectorial peculiarities of Russian education system development are the objects of peculiar interest of Kuzbass researchers [9-10]. The main directions of specialists' preparing for mineral resource extracting are shown in the some papers [11-12].

Today, in Russian Federation, the model of national educational system is built in accordance with the Federal Law "On Education in Russian Federation" [13]. In this normative document, the levels of education that exist on the territory of Russia are indicated: general (preschool, primary, basic secondary general) and professional (secondary, higher bachelor, special, magistracy, and research personnel training). Consequently, additional professional education is not allocated to a separate level of education. Educational services in this area can be provided by any educational institution.

\section{Results and Discussion}

Additional professional education should be understood as the kind of vocational education, which is obtained in addition to secondary or higher education. The basic rules regulating the process of additional vocational education are specified in Art. 76 of Russian Federation Federal Law "On Education in the Russian Federation".

Vocational professional education in Russia is divided into types, which include programs of professional development and professional re-training. The main criterion for training under these programs is the availability of professional education. These programs allow to raise the professional level to citizens who have a qualification or to master a new kind of professional activity.

Each industry has specific professional requirements, meanwhile, the general tendencies in education development testify to the limitation and closure of economic, managerial and legal specialties in Russian higher education institutions. Nevertheless, higher and additional professional education in mineral resource extracting area is expands in Russia. According to the hh.ru site, more than $50 \%$ of vacancies in the mineral resource extracting segment of labor market are lawyers which indicates the need for special training or retraining of personnel for this direction. Therefore, there is a need in "re-graduation" of a graduate from economic or legal university, which, in fact, received only general basic knowledge which is not always matching the specificity of mining industry. As a result, the employer faces the priority task of creating in the company a system of training or retraining employees at the sectoral level, in the parent organization, industry associations, especially created professional training and retraining centers. It should be noted that there is no training of individual specialists in sectoral universities in Russia existing. For example, none of the industry-specialized higher education institutions prepares financiers, however, in the current conditions of management, limited resources and instability of the business environment, the role of financial management of mineral resource extracting companies is growing permanently. And in order to competently manage finances, you need a clear understanding of the production process carried out by mineral resource extracting companies. 
Currently, the universities are developing two types of services for additional professional education. Let us analyze them in more detail. The first type of service is professional retraining. It involves a 900-hour training course. Depending on the educational institution, the amount of classroom hours varies on average from 250 to 500 hours. The rest of the time is allocated for self-training. Based on the results of the program, students receive a diploma of retraining. At the same time, among the studied disciplines, only one discipline in management and economics is encountered among experts in the field of mining or surveying. In some universities, a certificate of qualification is issued. In this case, the students get the right to perform a new type of professional activity.

The analysis of the market of additional education for mining specialists, carried out by us, indicates a wide range of programs being implemented. For example, professional retraining in the field of mining education is carried out in the areas of intra-industry bases, for example: "Mine Surveying"; "Engineering and geodesic surveys for construction"; "Rational use and protection of mineral resources"; "Geology"; "Land management and land cadaster"; "Industrial safety of hazardous production facilities"; "Organization of Personnel Service and Personnel Management in Mineral Resource Extracting"; "Environmental protection in mineral resource extracting".

The second block of programs is the programs of professional development. Their main task is to improve the educational level of employees. The target audience of such programs is the specialists who are required to undergo professional development every three years. The main goal of these programs is to improve skills and experience of industry workers. These programs involve training with a time budget of 16 hours or more. They allow improving professional knowledge in the field of mining.

It should be noted that for qualified management, including the sphere of mineral resource extracting these programs will not be enough. Specialists of the middle and senior level can improve their managerial effectiveness using programs of business education. Their training duration and list of activities studied differ from the two previous types of programs. As a rule, they are in demand among specialists who have a diploma of higher education. Some of the programs are selected for admission (for example, to the "Presidential program"), which is absent in the two previous types of programs.

As a result, the conducted research allows asserting that it is expedient to subdivide programs of additional professional education for specialists in the field of mineral resource extracting into three types. These programs are in demand by different specialists working in the industry. Some of them are in demand by land-surveyors, geologists, etc., the other economists, financiers, lawyers:

1. Professional retraining programs.

2. Business education programs (seldom take into account the specifics of the industry): DBA, EMBA, MBA, MPA; programs on international certification; corporate educational programs; state certification; presidential program for the training of management personnel.

3. Professional development programs - seminars, trainings, etc.

Today these programs are implemented both on the basis of industry sectorial universities and consulting agencies. When implementing a program at the university, it is advisable to take into account the differences in methods, forms, approaches to the organization of the educational process and the assessment of knowledge of the students. First of all, along with theoretical issues, in-depth practical aspects of the chosen topic should be considered. Secondly, the methodology for testing knowledge should be built taking into account the psychological characteristics of adult learning. Thirdly, it is expedient to conduct classes in an interactive form, which helps to determine the degree of mastering the material of each participant in the learning process. 
A study of the forms of additional professional education programs implementation showed that in most universities and training centers a remote form is used. Programs in the field of mineral resource extracting are no exception.

Many universities develop their own portals and give their students the remote access to them. On the portal you can get acquainted with the materials on a certain problematic, which can represent both lectures and scientific developments on the theory and history of the issue under study. However, almost all educational institutions provide these services for a fee. Portals of distance education are actively developing, on the basis of the active use of computer technologies. They have already laid out the courses of leading universities on "Engineering Geology", "Hydrogeology", "Mining Engineering”. Some of these courses are free. However, as can be seen from the list, this is not enough for full qualification improvement. At the same time, there are no courses on the economics of the industry, industry finance or mining legistation.

Our study of online educational projects has shown that almost all of them are made not in Russia. The name of the projects and the specificity of the material provided for them are given in Table 1.

Table 1. Remote portals used for obtaining professional skills, including the field of mineral resource extracting engineering and their content.

\begin{tabular}{|c|c|}
\hline Project name & Materials tutoring on the educational platform \\
\hline $\begin{array}{l}\text { Coursera, Study the } \\
\text { new }\end{array}$ & Courses on a wide range of subjects \\
\hline Zillion & $\begin{array}{c}\text { Articles and webinars on doing business, realizing } \\
\text { business ideas and career building }\end{array}$ \\
\hline $\begin{array}{l}\text { Universarium, Open } \\
\text { Education }\end{array}$ & Courses of lectures on the disciplines \\
\hline Eduson & $\begin{array}{c}\text { Educational courses on doing business in Russian and } \\
\text { English }\end{array}$ \\
\hline Uniweb & $\begin{array}{l}\text { Courses and educational programs of additional } \\
\text { professional education in the field of economy, finance, } \\
\text { development of e-courses, etc. }\end{array}$ \\
\hline DigitalOctober & Courses, translated into Russian, "Open Laboratories" \\
\hline Univer.tv & Lectures, educational movies, speeches at conferences. \\
\hline Intuit.ru & $\begin{array}{l}\text { Lecture courses for bachelor's degree and advanced } \\
\text { training courses mainly in IT }\end{array}$ \\
\hline Hexlet (hexlet.org) & IT courses \\
\hline Lektorium.tv & A library of video lectures on various topics \\
\hline Businesslearning.ru & Business education courses \\
\hline $\begin{array}{c}\text { Netology } \\
\text { (netology.ru) }\end{array}$ & Courses and webinars on IT topics \\
\hline $\begin{array}{l}\text { University without } \\
\text { borders }\end{array}$ & Courses on the methodology \\
\hline
\end{tabular}

Distance courses on most platforms are not fee, that allows them developing actively and depriving a part of the educational institutions of listeners. Consequently, the future of Russian additional education is the portals of distanced education with a variety of courses on sectoral subjects.

\section{Conclusion}

The conducted research showed that the programs of additional education in mineral resource extracting should be divided into programs of professional retraining, advanced 
training and business education, since the requirements for each of the programs listed are different. These programs are in demand in the market of educational services in Russia. At the same time, there is an increasing demand for distance learning programs. However, the emergence of educational platforms and courses in the result may adversely affect the traditional forms of education in universities and training centers. Therefore, even today, for the purposes of advertising, it is necessary to introduce new courses in mineral resource extracting area to remote platforms, as well as for economics, finance and jurisprudence, taking into account the industry specific features of specialists training.

\section{References}

1. M.A. Gasanov, K.A. Kolotov, K.A. Demidenko, E.A. Podgornaya, O.V. Kadnikova, IOP Conf. Ser.: Earth Environ. Sci., 50:1, 012025 (2017)

2. I. Pevneva, O. Gavrishina, A. Rolgayzer, M. Agienko, A. Myaskov, E3S Web of Conf., 15, 04016 (2017)

3. V.B. Frolova, O.A. Kalugina, L.S. Artamonova, A.I. Boykov, IEJME: Math. Educ. 11:5, 1185-1193 (2016)

4. O.V. Borisova, D.G. Vasbieva, V.B. Frolova, E.M. Merzlikina, IEJME: Math. Educ. 11:7, 2483-2491 (2016)

5. O.V. Borisova, D.G. Vasbieva, N.I. Malykh, S.A.Vasnev, IEJME: Math. Educ. 11:5, 1175-1184 (2016)

6. F. Agafonov, A. Genin, O. Kalinina, O. Brel, O. Zhironkina, E3S Web of Conf., 15, 04011 (2017)

7. S.A. Zhironkin, K.A. Kolotov, O.V. Zhironkina, Economics and Innovation Management, 1, 4-16 (2017) DOI: 10.26730/2587-5574-2017-1-4-16

8. S. Anyona, B.K. Rop, Economics and Innovation Management, 1, 17-29 (2017) DOI: 10.26730/2587-5574-2017-1-17-29

9. V. Trifonov, O. Loyko, D. Nesteruk, S. Zhironkin, E. Strekovtsova, AIP Conf. Proceed., 1800, 050009 (2017)

10. S.A. Zhironkin, K.A. Kolotov, A.E. Genin, F.V. Agafonov, S.A. Kovalevsky, IOP Conf. Ser.: Earth Environ. Sci., 50:1, 012011 (2017)

11. M. Cehlár, J. Janočko, Z. Šimková, T. Pavlik, E3S Web of Conf., 15, 01019 (2017)

12. S.A. Zhironkin, Ugol', 4, 47-49 (2002)

13. Federal Law of Russian Federation "On Education in Russian Federation”, December 29, 2012, No 273-FZ 
